\title{
GENETIC DIVERGENCE AMONG 22 STRAWBERRY (Fragaria $x$ Ananassa Duch.) GENOTYPES FOR BIOACTIVE COMPOUNDS GROWN IN NORTH WEST HIMALAYAS
}

\author{
S. Lal ${ }^{*}$ and D. B. Singh \\ Division of Crop Improvement, Central Institute of Temperate Horticulture, \\ Srinagar (J\&K)-190007, India
}

\begin{abstract}
To analyze genetic divergence 22 strawberry genotypes (Fragaria $x$ ananassa Duch.) were studied for six bioactive compounds traits at Central Institute of Temperate Horticulture $(\mathrm{CITH})$, Srinagar, India. The maximum PCV and GCV were estimated for the total phenol content (23.78 and 23.87) followed by vitamin $C(22.39$ and 22.48). The heritability was highest for total phenols (99.61\%) and DDPH (99.18). Genotypic correlation was of higher magnitude to the corresponding phenotypic ones. Titrable acidity exhibited highly negative association with vitamin $\mathrm{C}$ whereas total phenol content was showed significantly negative correlation with vitamin $C$ but positive association with titrable acidity and total anthocyanin contents. DPPH and vitamin $\mathrm{C}$ negatively correlated, however DPPH exhibited highly positive and significant association with titrable acidity, total anthocyanin and total phenol contents. In path analysis, highest positive direct effect was exhibited by total phenol content $(0.937)$ the highest negative direct effect by total flavonols $(-0.055)$. The selection based on higher total phenols, titrable acidity and total anthocyanin contents will be beneficial for enhancing the total antioxidant potential attributes of strawberry germplam for commercial utilization and processing. The information also could be utilized to increase the nutritional value of different foods and diets in the prevention of chronic human diseases using strawberry genotypes having higher bioactive compounds.
\end{abstract}

Keywords: Strawberry, genetic divergence, correlation, genetic variability, heritability, path analysis

* Corresponding author email: shivcith@gmail.com

Received: 20.03.2106 


\section{INTRODUCTION}

Strawberries belong to the genus Fragaria that consists of several diverse species of varying ploidy levels with a wide geographic distribution among species (Hancock, 1999). It is one of the most preferred and excellent berry fruit for its sweet flavor and attraction. There are more than 20 species and 600 strawberry cultivars in the world differing in flavor, size and texture (Lal et al., 2015; Anon, 2013). Its fruits are very nutritious, good as dietary source of fiber and bioactive compounds. Berry fruits contain different antioxidant bioactive compounds and the polyphenolic contents among different cultivars vary significantly. In particular phenolic composition seems to strongly influence fruit quality by contributing to sensorialorganoleptic qualities and nutritional values (Deighton et al., 2000). Due to rise in health consciousness among the consumers about intake of health promoting substances, the demand of antioxidant rich fruits increased significantly worldwide. Furthermore, recent scientific evidences pointed out the importance of health promoting compounds in strawberries in relation to their high level of antioxidants including vitamin $C$ and phenolic compounds (Tulipani et al., 2008). The antioxidant and health promoting potential were studied by many researchers in strawberry (Zhang et al., 2008). Several evidences suggested the antioxidant activity of polyphenols from a variety of plant sources and their primary role in cell damage prevention related to the exposition to high level of reactive oxygen species (Proteggente et al., 2002) Many fruits particularly strawberry and cane fruits are rich source of phenolics, vitamin and minerals (Hoppula and Karhu, 2006). Correlation in conjunction with path analysis helps in identifying suitable selection criteria for improving bioactive compounds through breeding and for future crop improvement programmed. Detailed information on antioxidant properties of these cultivars with desired genetic architecture rich in nutraceutical content will serve as a reference material to develop nutraceutical rich strawberry. Generation of such information will benefit breeders, processors and general consumer. Genetic divergence studies of strawberry germpalsm on the basis morpho- physico-chemical attributes have been done earlier by several workers. But information on variability among strawberry genotypes for bioactive compounds under Indian temperate conditions are scanty. Hence, the present investigation was undertaken to assess genetic divergence among the 22 strawberry genotypes for six different bioactive compounds, their correlation with each other and their direct and indirect contribution to total antioxidant potential.

\section{MATERIALS AND METHODS}

The present study was carried out at the research farm of Central Institute of Temperate Horticulture (CITH), Srinagar, Jammu and Kashmir, India. The experimental farm is situated at $34^{\circ} 05 \mathrm{~N}$ latitude and $74^{\circ} 50 \mathrm{E}$ longitudes at an altitude of $1640 \mathrm{~m}$ above the mean sea level. The 22 strawberry genotypes viz. Katrain Sweet, Dilpasnd, Red Cross, Larson, Camma Rosa, Elstar, Athena, EC- 
102642, Fiona, Banglora, Douglus, Senga Sangne, Majestic, Phenomenal, EC-22355, Shasta, Black More, Heera, Chandlar, Brihgton, Howard and Missionary were used for the study. A complete randomized block design (CRBD) replicated three times and average data of two years were analyzed as per the method suggested by (Gomez and Gomez, 1994). Each experimental plot was $4.5 \mathrm{~m}^{2}$ apart. The distance between strawberry transplants was $25 \mathrm{~cm}$ and between rows was $17 \mathrm{~cm}$. The planting dates were on 15 October 2010 and 2011. Recommended production practices were followed for raising healthy crop. Fruits were harvested at commercial ripened during first fortnight of May, 2011-12 from randomly selected plants to represent the population of the plantation. The average maximum temperature $19.63^{\circ} \mathrm{C}$, minimum $6.52{ }^{\circ} \mathrm{C}$, rainfall $160.72 \mathrm{~cm}$ and relative humidity $58.35 \%$, evaporation $2.45 /$ day and soil characteristics viz. $\mathrm{pH}=6.81, \mathrm{EC}=0.36 \mathrm{ds} \mathrm{m}^{-1}$ were recorded during both growing seasons. Randomly collected fruits of strawberry were brought to labs and squeezed manually under ice, filtered with a sieve and centrifuged for $5 \mathrm{~min}$ at $500 \mathrm{~g}$. The phenol content was measured by the Folin- Ciocalteau reagent (Aaby et al., 2005) using gallic acid as standard. Total antioxidant potential measures in terms of DPPH (2, 2-diphenyl-1-picrylhydrazyl) was determined according to the method used by Yen and Chen (1995) with some modifications. A $1 \mathrm{~mL}$ aliquot of strawberry juice was diluted 200 times and then $3 \mathrm{~mL}$ of ethanol $(96 \%)$ and $1 \mathrm{~mL}$ of DPPH $(0.012 \mathrm{~g} \mathrm{DPPH} \cdot 100 \mathrm{~mL})$ were added. The mixture was shaken and left at room temperature for $10 \mathrm{~min}$; the absorbance was measured spectrophotometrically at 517 $\mathrm{nm}$ and reported as mg ascorbic acid equivalent (AAE) $100 \mathrm{~g}$ fresh weight. The total flavonoids content was determined using a colorimetric method (Kim et al., 2003). Ascorbic acid contents of fresh fruit were determined spectrophotometrically by metaphosphoric acid extraction of 2,6-dichlorophenol indophenol dye (Robinson et al., 1945). Titrable acidity was determined by using method given in (AOAC, 1994). Anthocyanins were determined according to (Shin et al., 2008) with some modifications. Total anthocyanins content was calculated using the extinction coefficient $(\varepsilon)$ equal to $3.6 \times 106 \mathrm{~mol}^{-1} \mathrm{~m}^{-1}$. Total anthocyanin content was expressed as mg cyanidin-3-hydrochloride equivalent kg-1FW. Data were subjected to analysis of variance (ANOVA) as per Gomez and Gomez (1994). The genotypic and phenotypic coefficients of variation were calculated using the formulae of Burton and De Vane (1953). Heritability and genetic advance were calculated according to Allard (1960) and genetic gain was estimated using the method of Johanson et al. (1955). Genotypic and phenotypic correlations were calculated as per Al-Jibouri et al. (1958) using an ANOVA and covariance matrix in which total variability was split into replications, genotypes, and errors. The genotypic and phenotypic correlation coefficients were used to determine direct and indirect contribution toward yield per plot. The direct and indirect paths were obtained according to the method of Dewey and Lu (1959). 


\section{RESULTS}

The extent of variability in respect of range, mean, phenotypic \& genotypic coefficients of variation, heritability and genetic advance is given in table 1. Maximum variability recorded in total phenol content ranged from 372.45-914.29 followed by total antioxidant potential (DPPH) 199.38-481.12, vitamin-C 50.4091.27, total flavonols 31.07-56.56, total anthocyanine 28.01- 44.35 and least in titrable acidity $0.727-1.46$. Phenotypic coefficient of variation was recorded higher than genotypic coefficient of variation for all the characters studied. Maximum PCV and GCV estimated for the total phenol content (23.78 and 23.87) followed by total antioxidant potential $(22.48,22.39)$, titrable acidity $(18.55,18.43)$, vitamin-C (15.73, $15.61)$, total flavonols $(13.88,13.69)$ and total anthocyanin contents $(12.74,12.56)$. The heritability was highest for total phenols (99.61\%) followed by DDPH $(99.18 \%)$, titrable acidity (98.67), vitamin-C (98.30), total flavonols (97.12) and least in total anthocyanin (97.07). Total phenols, total antioxidant potential (DPPH) and titrable acidity exhibited high heritability coupled with high genetic coefficient of variation. Maximum genetic advance (\%) and genetic advance percent of mean was recorded for total phenols $(299.08,48.79)$ followed by total antioxidant potential (DPPH $153.48,45.94)$ and minimum in total anthocyanin contents $(9.30,25.49)$ respectively.

Table 1. Estimate of genetic parameters for bioactive compounds traits in 22 strawberry genotypes

\begin{tabular}{|c|c|c|c|c|c|c|c|}
\hline Characters & Range & $\begin{array}{l}\text { Mean } \pm \\
\operatorname{SE}(m)\end{array}$ & $\begin{array}{c}\text { Genotypic } \\
\text { coefficient } \\
\text { of } \\
\text { variation } \\
(\mathrm{GCV} \%)\end{array}$ & $\begin{array}{c}\text { Phenotypic } \\
\text { coefficient of } \\
\text { variation } \\
\text { (PCV \%) }\end{array}$ & $\begin{array}{c}\text { Heritability } \\
\%\end{array}$ & $\begin{array}{c}\text { Genetic } \\
\text { Advance } \%\end{array}$ & $\begin{array}{l}\text { GA\% } \\
\text { of } \\
\text { mean }\end{array}$ \\
\hline $\begin{array}{l}\text { Vitamin C (mg/100 } \mathrm{g} \text { of } \\
\text { fresh weight) }\end{array}$ & $\begin{array}{l}50.40- \\
91.27\end{array}$ & $\begin{array}{l}72.55 \pm \\
2.44\end{array}$ & 15.61 & 15.739 & 98.30 & 23.12 & 31.87 \\
\hline Titrable acidity (\%) & $\begin{array}{l}0.727- \\
1.465\end{array}$ & $\begin{array}{l}1.01 \pm \\
0.012\end{array}$ & 18.43 & 18.552 & 98.67 & 0.38 & 37.71 \\
\hline $\begin{array}{l}\text { Total anthocyanin (mg } \\
\text { pelargonidin-3-glucoside } \\
\left.\text { equivalents } 100 \mathrm{~g} \_1 \mathrm{fw}\right)\end{array}$ & $\begin{array}{l}28.01- \\
44.35\end{array}$ & $\begin{array}{l}36.49 \pm \\
0.453\end{array}$ & 12.56 & 12.746 & 97.07 & 9.30 & 25.49 \\
\hline $\begin{array}{l}\text { Total phenols (mg GA } \\
\text { equivalents } / 100 \mathrm{~g} \text { ) }\end{array}$ & $\begin{array}{l}372.45- \\
914.29\end{array}$ & $\begin{array}{l}612.97 \\
+6.77\end{array}$ & 23.78 & 23.873 & 99.21 & 299.08 & 48.79 \\
\hline $\begin{array}{l}\text { Total flavonols (mg } \\
\text { catechin equivalents } / 100 \\
\text { g) }\end{array}$ & $\begin{array}{l}31.07- \\
56.56\end{array}$ & $\begin{array}{l}43.34 \pm \\
0.549\end{array}$ & 13.69 & 13.887 & 97.12 & 12.04 & 27.78 \\
\hline $\begin{array}{l}\text { Total antioxidant } \\
\text { potential, DPPH (mg of } \\
\text { AAE } / 100 \mathrm{~g} \text { of fresh } \\
\text { weight }\end{array}$ & $\begin{array}{l}199.38- \\
481.12\end{array}$ & $\begin{array}{l}334.11 \\
+3.69\end{array}$ & 22.39 & 22.483 & 99.18 & 153.48 & 45.94 \\
\hline
\end{tabular}


Analysis of variance also showed significant differences among the genotypes for all the characters studied (Table 2). The genotypic and phenotypic correlation for fruits (berry) total antioxidant potential and contributing components are presented in table 3. The findings clearly indicated that genotypic correlation was of higher magnitude to the corresponding phenotypic ones, thereby establishing strong inherent relationship among the characters studied. Vitamin- $\mathrm{C}$ and titrable acidity exhibited highly negative significant genotypic and phenotypic association whereas total anthocyanin is non significantly associated with vitamin-C and titrable acidity traits. Total phenol content showed significantly negative correlation with vitamin $\mathrm{C}$ but positive highly significant association with titrable acidity and total anthocyanin contents. Total flavonols revealed negative non significant relation with vitamin $\mathrm{C}$, titrable acidity, total phenols and positive non significant association with total anthocyanin. Total antioxidant potential (DPPH) and vitamin C negatively significantly correlated whereas total antioxidant potential (DPPH) exhibited positively highly significant association with titrable acidity, total anthocyanin and total phenole contents.

Table 2. ANOVA important bioactive compounds traits studied in 22 strawberry genotypes

\begin{tabular}{l|c|c|c|l|c|c}
\hline $\begin{array}{c}\text { Source of } \\
\text { variation }\end{array}$ & $\begin{array}{c}\text { Vitamin C } \\
(\mathrm{mg} / 100 \mathrm{~g} \\
\text { of fresh } \\
\text { weight })\end{array}$ & $\begin{array}{c}\text { Titrable } \\
\text { acidity } \\
(\%)\end{array}$ & $\begin{array}{c}\text { Total } \\
\text { anthocyanin } \\
(\mathrm{mg} \\
\text { pelargonidin-3- } \\
\text { glucoside } \\
\text { equivalents } 100 \\
\left.\mathrm{~g} \_1 \mathrm{fw}\right)\end{array}$ & $\begin{array}{c}\text { Total phenols }(\mathrm{mg} \\
\mathrm{GA} \\
\text { equivalents/100 g) }\end{array}$ & $\begin{array}{c}\text { Total } \\
\text { flavonols (mg } \\
\text { catechin } \\
\text { equivalents } \\
/ 100 \mathrm{~g})\end{array}$ & $\begin{array}{c}\text { Total } \\
\text { antioxidant } \\
\text { potential as } \\
\text { DPPH (mg of } \\
\text { AAE /100 g } \\
\text { of fresh } \\
\text { weight })\end{array}$ \\
\hline Treatment & $368.73^{*}$ & $0.104^{*}$ & $63.61^{*}$ & $63906.24 *$ & $106.60 *$ & $16835.97 *$ \\
Replication & 148.58 & 0.004 & 23.87 & 2341.89 & 52.44 & 5687.90 \\
Error & 0.123 & 0.02 & 0.12 & 0.028 & 0.004 & 0.067 \\
\hline
\end{tabular}

*Significant at $\mathrm{p}<0.05$, 
Table 3. Phenotypic and genotypic correlations matrix among important bioactive compounds traits in 22 strawberry genotypes

\begin{tabular}{|c|c|c|c|c|c|c|}
\hline Characters & $\begin{array}{c}\text { Vitamin }- \\
\mathrm{C}(\mathrm{mg} / 100 \\
\mathrm{g} \text { of fresh } \\
\text { weight })\end{array}$ & $\begin{array}{l}\text { Titrable } \\
\text { acidity } \\
(\%)\end{array}$ & \begin{tabular}{|c} 
Total \\
anthocyanin \\
(mg \\
pelargonidin-3- \\
glucoside \\
equivalents 100 \\
g_1 fw)
\end{tabular} & $\begin{array}{c}\text { Total phenols }(\mathrm{mg} \\
\text { GA } \\
\text { equivalents } / 100 \mathrm{~g})\end{array}$ & \begin{tabular}{|c} 
Total \\
flavonols $(\mathrm{mg}$ \\
catechin \\
equivalents \\
$/ 100 \mathrm{~g})$
\end{tabular} & $\begin{array}{c}\text { Total } \\
\text { antioxidant } \\
\text { potential as } \\
\text { DPPH (mg of } \\
\text { AAE /100 g } \\
\text { of fresh } \\
\text { weight) }\end{array}$ \\
\hline $\begin{array}{l}\text { Vitamin }-\mathrm{C}(\mathrm{mg} / 100 \mathrm{~g} \text { of } \\
\text { fresh weight })\end{array}$ & $\begin{array}{l}\text { P } 1.000 \\
\text { G } 1.000\end{array}$ & & & & & \\
\hline Titrable acidity $(\%)$ & $\begin{array}{l}\mathrm{P}-0.454 * * \\
\mathrm{G}- \\
0.458^{* *}\end{array}$ & $\begin{array}{l}\text { P } 1.000 \\
\text { G } 1.000\end{array}$ & & & & \\
\hline $\begin{array}{l}\text { Total anthocyanin }(\mathrm{mg} \\
\text { pelargonidin-3-glucoside } \\
\left.\text { equivalents } 100 \mathrm{~g} \_1 \mathrm{fw}\right)\end{array}$ & $\begin{array}{l}\mathrm{P}- \\
0.206 \mathrm{NS} \\
\mathrm{G}- \\
0.294 \mathrm{NS}\end{array}$ & $\begin{array}{l}\mathrm{P} 0.132 \mathrm{NS} \\
\mathrm{G} \\
0.136 \mathrm{NS}\end{array}$ & $\begin{array}{l}\text { P } 1.000 \\
\text { G } 1.000\end{array}$ & & & \\
\hline $\begin{array}{l}\text { Total phenols (mg GA } \\
\text { equivalents } 100 \mathrm{~g} \text { ) }\end{array}$ & $\begin{array}{l}P-0.306^{*} \\
G-0.306^{*}\end{array}$ & $\begin{array}{l}\text { P } 0.391 * * \\
\text { G } 0.395 * *\end{array}$ & $\begin{array}{l}\mathrm{P} 0.544 * * \\
\mathrm{G} 0.449 * *\end{array}$ & $\begin{array}{l}\text { P } 1.000 \\
\text { G1.000 }\end{array}$ & & \\
\hline $\begin{array}{l}\text { Total flavonols (mg } \\
\text { catechin equivalents } / 100 \\
\text { g) }\end{array}$ & $\begin{array}{l}\mathrm{P}- \\
0.048 \mathrm{NS} \\
\mathrm{G}- \\
0.043 \mathrm{NS}\end{array}$ & $\begin{array}{l}\mathrm{P}- \\
0.204 \mathrm{NS} \\
\mathrm{G}- \\
0.201 \mathrm{NS}\end{array}$ & $\begin{array}{l}\text { G } 0.083 \mathrm{NS} \\
\mathrm{P} 0.086 \mathrm{NS}\end{array}$ & $\begin{array}{l}\text { P-0.023NS } \\
\text { G-0.025NS }\end{array}$ & $\begin{array}{l}\text { P } 1.000 \\
\text { G } 1.000\end{array}$ & \\
\hline $\begin{array}{l}\text { Total antioxidant } \\
\text { potential, DPPH (mg of } \\
\text { AAE } / 100 \mathrm{~g} \text { of fresh } \\
\text { weight }\end{array}$ & $\begin{array}{l}\mathrm{P}-0.294 * \\
\mathrm{G}-0.301 *\end{array}$ & $\begin{array}{l}\mathrm{P}-0.401 * * \\
\mathrm{G}- \\
0.407 * *\end{array}$ & $\begin{array}{l}\text { G } 0.581 * * \\
\text { P } 0.584 * *\end{array}$ & $\begin{array}{l}\text { G } 0.978 * * \\
\text { P } 0.980 * *\end{array}$ & $\begin{array}{l}\text { G }-0.077 \mathrm{NS} \\
\mathrm{P}-0.079 \mathrm{NS}\end{array}$ & $\begin{array}{l}\text { G } 1.000 \\
\text { P } 1.000\end{array}$ \\
\hline
\end{tabular}

Significant at $\mathrm{p}<0.05, * *$ significant at $\mathrm{p}<0.01$.

Path analysis also done to study the direct and indirect effect of different bioactive compounds on total antioxidant potential of strawberry genotypes and data are presented in table 4 . The highest positive direct effect was exhibited via total phenol content (0.937) followed by total anthocyanin (0.0778), titrable acidity (0.020) and vitamin C (0.012) however highest negative direct effect via total flavonols (-0.055). Vitamin $\mathrm{C}$ exhibited positive direct effect via total flavonols and negative indirect effect via titrable acidity, total anthocyanin and total phenols on total antioxidant potential (DPPH). Titrable acidity showed positive indirect effect via total anthocyanin, total phenols, total flavonols and negative indirect effect via vitamin C. Total anthocyanin exhibited positive indirect effect via titrable acidity and total phenols however negative indirect effect via vitamin-c and total flavonols. Total phenols revealed positive indirect effect via titrable acidity, total anthocyanin and total flavonols whereas negative indirect effect via vitamin C. Total flavonols 
exhibited positive indirect effect via total anthocyanin however negative indirect effect via vitamin $\mathrm{C}$, titrable acidity and. total phenols.

Table 4. Direct (bold) and indirect effects (unbold) of different bioactive compounds on total antioxidant potential of strawberry genotypes

\begin{tabular}{|c|c|c|c|c|c|c|}
\hline Characters & \begin{tabular}{|} 
Vitamin \\
$-\mathrm{C}$ \\
(mg/100 \\
$\mathrm{g}$ of \\
fresh \\
weight)
\end{tabular} & $\begin{array}{c}\text { Titrable } \\
\text { acidity }(\%)\end{array}$ & $\begin{array}{c}\text { Total } \\
\text { anthocyanin } \\
\text { (mg } \\
\text { pelargonidin-3- } \\
\text { glucoside } \\
\text { equivalents } 100 \\
\text { g_1 fw) }\end{array}$ & $\begin{array}{c}\text { Total phenols } \\
\text { (mg GA } \\
\text { equivalents } / 100 \\
\text { g) }\end{array}$ & \begin{tabular}{|c|} 
Total \\
flavonols \\
$(\mathrm{mg}$ \\
catechin \\
equivalents \\
$/ 100 \mathrm{~g})$
\end{tabular} & $\begin{array}{c}\text { Genotypic } \\
\text { correlation } \\
\text { with total } \\
\text { antioxidant } \\
\text { potential as } \\
\text { DPPH (mg of } \\
\text { AAE / } 100 \text { gm } \\
\text { of fresh weight }\end{array}$ \\
\hline $\begin{array}{l}\text { Vitamin }-\mathrm{C} \\
(\mathrm{mg} / 100 \mathrm{~g} \text { of } \mathrm{fw})\end{array}$ & 0.01221 & -0.00926 & -0.01628 & -0.29007 & 0.00238 & $-0.301^{*}$ \\
\hline $\begin{array}{l}\text { Titrable acidity } \\
(\%)\end{array}$ & -0.00559 & 0.02022 & 0.01060 & 0.37027 & 0.01169 & $0.407^{* * *}$ \\
\hline $\begin{array}{l}\text { Total anthocyanin } \\
\text { (mg pelargonidin- } \\
\text { 3-glucoside } \\
\text { equivalents } \\
\text { g_1 fw) }\end{array}$ & -0.00255 & 0.00275 & 0.07787 & 0.52150 & -0.00479 & $0.595^{* *}$ \\
\hline $\begin{array}{l}\text { Total phenols (mg } \\
\text { GA } \\
\text { equivalents } / 100 \mathrm{~g} \text { ) }\end{array}$ & -0.00378 & 0.00799 & 0.04334 & 0.93705 & 0.00150 & $0.986^{* *}$ \\
\hline $\begin{array}{lr}\text { Total flavonols } \\
(\mathrm{mg} & \text { catechin } \\
\text { equivalents } / 100 \mathrm{~g})\end{array}$ & -0.00052 & -0.00424 & 0.00668 & -0.02518 & -0.05582 & $-0.079^{\mathrm{NS}}$ \\
\hline
\end{tabular}

Residual are 0.0207

The residual effect was 0.020 , which indicates that the characters under study are sufficient for the path analysis.

\section{DISCUSSION}

The selected genotypes phenotypically and genotypically differed which showed significant variability (Table 1). Estimates of phenotypic and genotypic coefficients of variation indicated the amount of variation exist in the germplasm. For all characters studied, phenotypic coefficients of variation were higher than genotypic coefficients of variation, though the difference was small in some cases. The traits like total phenols, total antioxidant potential and titrable acidity were less influenced by environment demonstrating either these were simply inherited characters governed by a few major genes or additive gene effect even if, they were under polygenic 
control and therefore, selection of these characters would be more effective for yield improvement (Johnson et al., 1955; Panse and Sukhatme, 1957).

ANOVA also indicated significant differences among genotypes for all characters (Table 2). The estimate of genetic parameters of major traits contributing to antioxidant potential showed wide genetic diversity among the genotypes studied which implies the greater influence of environment in the expression of these characters. Buendia et al. (2010) also reported considerable variation for total and individual anthocyanins, flavonols and phenolics contents during a study with 15 strawberry cultivars. The genetic divergence among strawberry cultivars provides a basis for planning for future efficient utilization of genetic resources to realize the potentiality for augmenting qualitative breeding programme and source for making health foods.

Total phenols, DPPH and titrable acidity traits exhibited high heritability coupled with high genetic coefficient of variation which indicates those need selection over several successive generations following hybridization for their edification. Burton and Devane (1953) suggested that genotypic coefficient of variation along with heritability estimates would give better idea about the efficiency of selection. Similar results were also reported in blue berry (Connor et al., 2002a and 2002b). Therefore, it is always better that both the genetic parameters should be considered together. Genetic advance and genetic advance as percent of mean exhibited maximum value for total phenols followed by total antioxidant potential (DPPH). High heritability coupled with high genetic advance for traits suggest the potentiality of source material for improvement through selection for these traits.

The major causes underlying association are either due to pleiotropic gene action or linkage or both. The phenotypic correlation includes genotypic and environmental effects, which provides information about total association between the observable characters. The phenotypic correlations were normally of genetic and environmental interaction which provided information about the association between the two characters. Genotypic correlation provides a measure of genetic association between the characters normally used in selection. Whereas environmental as well as genetic architecture of a genotype plays a major role in achieving higher antioxidant potential combined with higher health promoting substances (Salandanan et al., 2014). The genotypic and phenotypic correlation for fruit (berry) antioxidant compounds and its component in strawberry are presented in table 3 . The findings clearly indicate that genotypic correlations were of higher magnitude to the corresponding phenotypic ones, thereby establishing strong inherent relationship among the characters studied. Highly significant positive association between total antioxidant potential and titrable acidity, total phenol and total anthocyanin could be exploited for nutritional improvement programmed. High positive correlation between total phenols and total antioxidant activity (DPPH, FRAP) reported in blueberries (Giovanelli and Buratti, 2009 and Moyer et al., 2002) and in strawberry 
by Tulipani et al. (2008). Similarly Ding et al. (2006) and Pantelidis et al. (2007) reported positive association between total antioxidant capacity and total anthocyanin in strawberry. Therefore more stress should be given on significantly positively related traits contributing towards total antioxidant potential to breed antioxidant rich genotypes and helpful for further improvement of the cultivars lacking bioactive compounds.

Path coefficient analysis is an important tool for partitioning the correlation coefficients into the direct and indirect effects of independent variables on a dependent variable. Two characters may show correlation, just because they are correlated with a common third one. In provides an effective means of a critical examination of specific forces action to produce a given correlation and measure the relative importance of each factor. In this analysis, fruit yield was taken as dependent variable and the rest of the characters were considered as undependable variables. The path coefficient analysis which splits total correlation coefficient of different characters into direct and indirect effects on total antioxidant potential (DPPH) in such a manner that the sum of direct and indirect effects is equal to total genotypic correlation (Table 4). Path coefficient analysis revealed that total phenols had highest direct positive contribution towards total antioxidant potential followed by total anthocyanin. High PCV, GCV and heritability estimates, coupled with high genetic gain, occurred for higher total phenols, titrable acidity, total anthocyanin and total antioxidant potential. Indicating that these characters are under additive gene effects and more reliable for effective selection. Therefore selection based on higher total phenols, titrable acidity and total anthocyanin contents will be beneficial for enhancing the total antioxidant capacity in strawberry germplam.

The residual effect was estimated very low which indicates that the characters under study were sufficient for the path analysis.

\section{CONCLUSION}

The present study indicates wide genetic divergence among the strawberry genotypes in antioxidant contents which demonstrating its potential use as a food additive and good source of antioxidants. Total phenols, titrable acidity and total anthocyanin were the major contributing characters contributing for higher total antioxidant potential attributes and selection based on these characters could be effective for developing antioxidant rich strawberry genotypes. They can be used for direct consumption as various kinds of beverages or as extracts of antioxidants to increase the nutritional value of different foods and diets in the prevention of chronic human diseases. Besides, cultivars with high antioxidant potential may be desirable for crop improvement programme to breed a variety with high nutraceuticals. 


\section{REFERENCES}

Aaby, K., Skrede, G., Wrolstad, R. E. 2005. Phenolic composition and antioxidant activities in flesh and achenes of strawberries (Fragraria ananassa). Journal of Agriculture Food Chemistry, 3: 4032-4040

Al-Jibouri, H. A., Millar, P. A., Robinson, H. P.1958. Genotypic and environmental variances and covariance in upland cotton crosses in inter-specific origin. Agronomy journal, 50:633-637

Allard, R.W. 1960. Principles of plant breeding. John Wiley \& Sons, New York

Anonymous. 2013. Strawberries. http://www.chathamdailynews.ca/2013/06/13/there-are-600varieties-of-strawberries-in-the-world

AOAC.1994. Official Methods of Analysis Association of Official Analytical Chemists 111 North $19^{\text {th }}$ street, suite 20, Ed. $16^{\text {th }}$, Arlington, Virginia, USA, pp. 2209-22016

Benzie, I., Strain, J. J. 1996. The ferric reducing ability of plasma (FRAP) as a measure of "antioxidant power": The FRAP assay. Annals of Biochemistry, 239: 70-76

Buendia, B., Gill, M. I., Tudela, J. A. 2010. HPLC-MS analysis of proanthocyanidine oligomers and other phenolics in 15 strawberry cultivars. Journal of Agriculture Food Chemistry, 58(7): 3916-3926

Burton, G. W., Devane, E. V. M. 1953. Estimating heritability from replicated clonal material. Agronomy Journal, 45:478-481

Connor, A. M, Luby, J. J., Tong, C. B. S. 2002a. Variability in antioxidant activity in blueberry and the correlations between different antioxidant activity assays. Journal of American Society of Horticultural Science, 127:238-244

Deighton, N., Brennan, R., Finn, C., Davies, H. V. 2000. Antioxidant properties of domesticated and wild Rubus species. Journal of Scientific Food and Agriculture, 80: 1307-1313

Dewey, J. R., Lu, K. H. 1959. A correlation and path analysis of components of crested wheat-grass seed production. Agronomy journal, 51:515-518

Ding, M. R., Wang, F.S., Bowman, L., Qian, Y., Castranova, V., Jiang, B., Shi, X. 2006 Cyanidin-3-glucoside, a natural product derived from blackberry, exhibits chemopreventive and chemotherapeutic activity. Journal of Biological Chemistry, 281:17359-17368

Giovanelli, G., Buratti, S. 2009. Comparison of polyphenolic composition and antioxidant activity of wild Italian blueberries and some cultivated varieties. Food Chemistry, 112:903-908

Gomez, K. A., Gomez, A. A. 1994. Statistical Procedures for Agricultural Research, 2nd Edn., John Wiley and Sons Inc., New York.

Hancock, J. F. 1999. Strawberries. CABI Publishing, Wallingford: UK; 1999.

Hoppula, K. B., Karhu, S. T. 2006. Strawberry fruit quality responses to the production environment. Journal of Food Agriculture and Environment, 4: 166-170 
Johnson, W.W., Robinson, H. F., Comstock, R. E. 1955. Genotypic and phenotypic correlation in soybeans and their implications in selection. Agronomy Journal, 47:477482

Kim, D. O., Jeong, S. W., Lee, C. Y.2003. Antioxidant capacity of phenol phytochemicals from various cultivars of plums. Food Chemistry, 81: 321-326

Lal, S., Ahmed, N., Singh, S. R., Singh, D. B., Sharma, O. C. and Kumar, R. 2013. Variability of health and bioactive compounds in strawberry (Fragaria $\mathrm{x}$ ananassa Duch.) cultivars grown under an Indian temperate ecosystem. Fruits, 68(5): 423-434

Moyer, R. A, Hummer, K. E., Finn, C. E., Frei, B., Wrolstad, R. E. 2002. Anthocyanins, phenolics, and antioxidant capacity in diverse small fruits: Vaccinium, Rubus, and Ribes. Journal of Agriculture Food Chemistry, 50: 519- 525

Panse, V. G., Sukhatme, P. V. 1957. Genetics of quantitative characters in relation to plant breeding. Ind J Genet. 17:318-328.

Pantelidis, G. E., Vasilakakis, M., Manganaris, G. A., Diamantidis, G. 2007. Antioxidant capacity, phenol, anthocyanin and ascorbic acid contents in raspberries, blackberries, red currants, gooseberries and cornelian cherries. Food Chemistry, 102: 777-783

Proteggente, A. R., Pannala, A. S., Paganga, G., Van Buren, L., Wagner, E., Wiseman, S., Van de Put, F., Dacombe, C. and Rice-Evans, C. A. 2002. The antioxidant activity of regularly consumed fruit and vegetables reflects their phenoloics and vitamin $\mathrm{C}$ composition. Free Radical Research, 36:217-233

Robinson, W. B. and Stotz, E. 1945. The indeophenolxylene extraction method for ascorbic acid and modifications for interfering substances. Journal of Biological Chemistry, 160: $217-225$

Salandanan, K., Bunning, M., Stonaker, F., Kulen, O. and Kendall, P. 2009. Comparative analysis of antioxidant properties and fruit quality attributes of organically and conventionally grown melons (Cucumis melo L.). Horticulture Science, 44(7):18251832

Shin, Y., Liu, R. H., Nock, J. F., Watkins, C. B. 2008. Harvest maturity, storage temperature and relative humidity affect fruit quality, antioxidant contents and activity, and inhibition of cell proliferation of strawberry fruit. Post harvest Biology and Technology, 49: 201-209.

Tulipani, S., Mezzetti, B., Capocasa, F., Bompadre, S., Beekuilder, J., Ric De Vos, CH., Capanoglu, E., Bovy, A. and Battino, M. 2008. Antioxidants, phenol compounds and nutritional quality of different strawberry genotypes. Journal of Agriculture Food Chemistry, 56: 696-704

Zhang, Y., Seeram, N. P., Lee, R., Feng, L., Heber, D.2008. Isolation and identification of strawberry phenolics with antioxidant and human cancer cell antiproliferative properties. Journal of Agriculture Food Chemistry, 56: 670-675 